\title{
PENGARUH PENGGUNAAN MEDIA POWERPOINT DENGAN PENDEKATAN METAKOGNITIF BERBASIS MASALAH TERHADAP HASIL BELAJAR FISIKA SISWA KELAS XI MIA 4 SMAN 2 PALU
}

\author{
Bonitalia, Hendrik Arung Lamba dan Sahrul Saehana \\ e-mail: liabonita10@yahoo.com \\ Program Studi Pendidikan Fisika FKIP Universitas Tadulako \\ Jl. Soekarno Hatta Km. 9 Kampus Bumi Tadulako Tondo Palu - Sulawesi Tengah
}

\begin{abstract}
Abstrak - Penelitian ini bertujuan untuk mengetahui pengaruh penggunaan media powerpoint dengan pendekatan metakognitif berbasis masalah terhadap hasil belajar fisika siswa kelas XI. Metode penelitian yang digunakan adalah eksperimen kuasi, dengan desain penelitian "The Non Equivalen Pretest-Posttest Design". Sampel penelitian adalah siswa kelas XI MIA 4 dengan jumlah siswa sebanyak 32 siswa. Instrumen yang digunakan adalah tes hasil belajar dan angket inventori pendekatan metakognitif. Analisis data tes dilakukan dengan teknik statistik uji-t dua pihak untuk menguji pengaruh media powerpoint dengan pendekatan metakognitif berbasis masalah terhadap hasil belajar fisika. Berdasarkan hasil pengolahan data penelitian, diperoleh rata-rata skor pretest 9,38 dan standar deviasi 1,93; sedangkan rata-rata skor untuk postest diperoleh 13,47 dan standar deviasi sebesar 2,14. Dari hasil pengujian hipotesis dua pihak (uji-t) diperoleh $t_{\text {hitung }}=3,55$ dan $t_{\text {tabel }}=2,00$ dengan taraf nyata $\alpha=0,05$. Dalam hal ini $t_{\text {hitung }}>t_{\text {tabel. }}$. Hal ini menyatakan bahwa terdapat perbedaan hasil belajar fisika siswa yang diberi perlakuan menggunakan media powerpoint dengan pendekatan metakognitif berbasis masalah dengan kelas siswa yang diberi perlakuan secara konvensional. Dengan media yang digunakan dalam proses pembelajaran, siswa menjadi lebih aktif dalam pembelajaran dan terampil dalam mengerjakan soal-soal yang dibangun oleh kesadaran dan kemampuan berpikirnya sendiri, maka pembelajaran dengan pendekatan metakognitif akan menyadarkan siswa tentang kognitif yang dimilikinya.
\end{abstract}

Kata Kunci : Media Powerpoint, Pendekatan Metakognitif, Hasil Belajar Fisika

\section{PENDAHULUAN}

Pada era teknologi dan informasi proses pembelajaran lebih ditekankan berpusat pada siswa (student centered). Siswa diharapkan dapat memperoleh informasi dari berbagai sumber, dan guru dituntut untuk dapat membimbing siswa sehingga mampu memperoleh informasi dengan baik. Informasi yang diperoleh siswa dalam pembelajaran diantaranya berupa pengetahuan. Pengetahuan yang berupa logika dan fisik tidak dapat ditransfer secara utuh dari pikiran guru ke pikiran siswa. Pengetahuan tersebut harus dibangun di dalam pikiran siswa sendiri sebagai usaha keras untuk mengorganisasi pengalamannya.

Upaya untuk meningkatkan sikap aktif, kreatif, dan inovatif dari siswa tidaklah mudah. Kecenderungan yang terjadi adalah guru dianggap sumber belajar yang paling benar. Selain itu, proses pembelajaran yang terjadi seringkali memposisikan siswa sebagai pendengar ceramah guru. Akibatnya proses belajar mengajar cenderung membosankan dan menjadikan siswa malas belajar. Sikap anak didik yang pasif tersebut tidak hanya terjadi pada mata pelajaran tertentu tetapi pada hampir semua mata pelajaran termasuk fisika. Selama proses pembelajaran, siswa seharusnya ikut terlibat secara langsung agar siswa memperoleh pengalaman dari proses pembelajaran, Agustina (1). Keberhasilan proses kegiatan belajar mengajar pada pembelajaran fisika dapat diukur dari keberhasilan siswa yang mengikuti kegiatan tersebut. Keberhasilan itu dapat dilihat dari tingkat pemahaman dan penguasaan materi serta prestasi belajar siswa. Pemahaman dapat dicapai dengan menumbuhkan sikap aktif, kreatif dan inovatif pada siswa.

Proses pembelajaran memiliki dua aspek yang menonjol yaitu metode dan media pembelajaran sebagai alat bantu mengajar. Kedudukan media pembelajaran ada dalam metode pembelajaran. Oleh karena itu, fungsi utama dari media pembelajaran adalah sebagai alat bantu mengajar untuk menunjang penggunaan metode pembelajaran yang digunakan oleh guru, Arsyad (2). Salah satu cara untuk menyimpan informasi di dalam ingatan diperlukan media pembelajaran yang tepat. Media pembelajaran 
powerpoint dirasa sangat tepat untuk mengatasi hal tersebut, karena media ini memberikan informasi secara audiovisual sehingga siswa menyerap informasi dengan melihat, mendengar dan merespon dengan kemampuan mengingat siswa masing-masing sehingga pesan informasi secara visual mudah dipahami oleh siswa. Selain itu, media ini lebih merangsang siswa untuk mengetahui lebih jauh informasi tentang bahan ajar yang sedang disajikan. Objek yang ditampilakan terlihat konkret (nyata), penyajian powerpoint yang variatif karena terdapat aplikasi gambar, animasi, sound, video sehingga membuat proses pembelajaran tidak menjenuhkan.

Informasi atau konsep fisika yang panjang dan rumit tidak seharusnya dihafal begtu saja. Namun perlu diproses sampai kita bisa paham dan selalu ingat. Kegiatan pemrosesan tersebut memang perlu cara atau strategi. Salah satu jenis strategi yang dapat membantu siswa menjadikan informasi yang diterima menjadi informasi yang mudah diingat dan dipahami adalah strategi metakognitif, Maulana (3).

Menurut Lucky dan Madewi (4), metakognitif atau metakognisi adalah sesuatu yang berhubungan dengan berpikir siswa tentang cara berfikir mereka sendiri dan kemampuan mereka menggunakan strategi belajar-belajar tertentu dengan tepat. Pengetahuan seseorang berkenaan dengan proses dan produk kognitif orang itu sendiri atau segala sesuatu yang berkaitan dengan proses dan produk tersebut, sebagai contoh, pembelajaran sifat-sifat yang relevan dari informasi atau data. Dalam konteks pembelajaran, siswa mengetahui bagaimana untuk belajar, mengetahui kemampuan dan modalitas belajar yang dimiliki dan mengetahui strategi belajar terbaik untuk belajar efektif.

\section{METODE PENELITIAN}

Jenis penelitian yang digunakan pada penelitian kali ini dilihat dari teknik yang digunakan adalah penelitian kuasi eksperimen. Adapun desain penelitian yang digunakan yaitu desain prates-pascates kelompok kontrol tanpa acak. Desain penelitian yang digunakan dapat dilukiskan seperti pada Tabel 1 . Sudjana dan Ibrahim (5)

Tabel 1 Desain Prates-Pascates Kelompok Kontrol Tanpa Acak

\begin{tabular}{|c|c|c|c|}
\hline Kelompok & Prates & Perlakuan & Pascates \\
\hline $\mathrm{E}$ & $\mathrm{T}_{1}$ & $\mathrm{X}_{1}$ & $\mathrm{~T}_{2}$ \\
\hline $\mathrm{K}$ & $\mathrm{T}_{1}$ & $\mathrm{X}_{2}$ & $\mathrm{~T}_{2}$ \\
\hline
\end{tabular}

Keterangan:

$\mathrm{X}_{1}$ : Perlakuan (Treatment) dengan pemberian pembelajaran menggunakan powerpoint dengan pendekatan metakognitif (kelas eksperimen)
$\mathrm{X}_{2}$ : Perlakuan (Treatment) dengan pemberian pembelajaran konvensional (kelas kontrol)

$\mathrm{T}_{1}$ : Tes awal

$\mathrm{T}_{2}$ : Tes akhir

$\mathrm{T}_{1}=\mathrm{T}_{2}$

Penelitian dilakukan di SMA Negeri 2 Palu, Jalan Tanjung Dako No.9 Palu. Populasi dalam penelitian ini adalah seluruh siswa kelas XI MIA SMA Negeri 2 Palu tahun pelajaran 2014/2015 yang terdiri dari 8 kelas. Sampel dalam penelitian ini adalah kelas XI MIA 4 dan XI MIA 5. Teknik pengumpulan sampel yang digunakan adalah purposive sampling, yaitu teknik penentuan sampel dengan pertimbangan tertentu.

Berdasarkan hasil validitas ahli, pada awalnya terdiri dari 30 item soal kemudian disetujui sebanyak 20 item soal yang siap digunakan. Soal telah divalidasi oleh ahli kemudian dikoreksi dan disesuaikan dengan tujuan pembelajaran yang ingin dicapai.

Data yang dikumpulkan dari penelitian ini selanjutnya diolah dengan menggunakan teknik statistik, yaitu dengan menggunakan uji normalitas, uji homogenitas. Jika sebaran data berdistribusi normal dan homogen, maka data yang diperoleh dianalisis dengan menggunakan uji hipotesis (uji-t). Kriteria pengujianya adalah $\mathrm{H}_{\mathrm{o}}$ terima jika $-\boldsymbol{t}_{\left(1-\frac{1}{2} \alpha\right)}<$ $t<\boldsymbol{t}_{\left(\mathbf{1}-\frac{1}{2} \alpha\right)}$ dimana $\boldsymbol{t}_{\left(\mathbf{1}-\frac{1}{2} \alpha\right)}$ didapat dari daftar distribusi t dengan $\mathrm{dk}=\left(\mathrm{n}_{1}+\mathrm{n}_{2}-2\right)$ dan peluang $\boldsymbol{t}_{\left(\mathbf{1}-\frac{1}{2} \alpha\right)}$ dalam taraf nyata dengan $a=0,05$. Untuk harga-harga $t$ lainnya Ho ditolak.

\section{HASIL PENELITIAN DAN PEMBAHASAN} Deskripsi Hasil Pretest-Posttest

Pada penelitian ini digunakan dua kelas sebagai sampel dengan jumlah siswa pada masing-masing kelas sebanyak 32 orang. Banyaknya soal yang digunakan pada penelitian ini, baik soal pretest maupun posttest masing-masing berjumlah 20 item. Berdasarkan hasil pemberian pretest diketahui skor rata-rata kelas eksperimen sebesar 9,38 dengan standar deviasi sebesar 1,93. Untuk kelas kontrol, skor rata-ratanya sebesar 8,59 dan standar deviasi sebesar 2,65. Selanjutnya pada posttest, skor ratarata kelas eksperimen sebesar 13,47 dengan standar deviasi 2,14 dan untuk kelas kontrol skor rata-ratanya sebesar 12,63 dengan standar deviasi sebesar 2,03.

Tabel 2 Deskripsi skor tes hasil belajar fisika kelas eksperimen dan kelas kontrol (Pretest-Posttest).

\begin{tabular}{|c|c|c|c|c|}
\hline \multirow{2}{*}{ Uraian } & \multicolumn{2}{|c|}{ Pretest } & \multicolumn{2}{c|}{ Posttest } \\
\cline { 2 - 5 } & $\mathrm{E}$ & $\mathrm{K}$ & $\mathrm{E}$ & $\mathrm{K}$ \\
\hline $\begin{array}{c}\text { Sampel } \\
(\mathrm{n})\end{array}$ & 32 & 32 & 32 & 32 \\
\hline
\end{tabular}




\begin{tabular}{|c|c|c|c|c|}
\hline $\begin{array}{c}\text { Skor } \\
\text { rata-rata }\end{array}$ & 9,38 & 8,59 & 13,47 & 12,63 \\
\hline SD & 1,93 & 2,65 & 2,14 & 2,03 \\
\hline
\end{tabular}

Uji Normalitas

Pengujian data normalitas data penelitian ini peneliti menggunakan Chi-kuadrat dengan kriteria penerimaan $X^{2}$ hitung $<X^{2}$ tabel, taraf signifikan $a=0,05$, dan derajat kebebasan $\mathrm{dk}=\mathrm{k}-3$. Data yang digunakan untuk menguji normalitas data meliputi tes awal dan tes akhir hasil belajar baik kelas eksperimen maupun kelas kontrol. Hasil uji normalitas tes awal dan tes akhir dari kelas eksperimen dan kelas kontrol dapat dilihat pada Tabel 3.

Tabel 3 Hasil Uji Normalitas Tes Awal dan Tes Akhir Kelas Eksperimen dan Kelas Kontrol

\begin{tabular}{|c|c|c|c|c|}
\hline \multirow{2}{*}{ Uraian } & \multicolumn{2}{|c|}{ Tes Awal } & \multicolumn{2}{c|}{ Tes Akhir } \\
\cline { 2 - 5 } & Eksperimen & Kontrol & Eksperimen & Kontrol \\
\hline Sampel & 32 & 32 & 32 & 32 \\
\hline $\mathbf{x}_{\text {Hitung }}^{2}$ & 6,32 & 2,39 & 4,84 & 3,02 \\
\hline $\mathbf{x}_{\text {tabel }}^{2}$ & \multicolumn{2}{|c|}{7,81} & \multicolumn{2}{c|}{7,81} \\
\hline Ket & \multicolumn{2}{|c|}{ Normal } & \multicolumn{2}{c|}{ Normal } \\
\hline
\end{tabular}

Berdasarkan uji normalitas pada Tabel 2 dengan menggunakan Chi-kuadrat dengan kriteria penerimaan $\mathrm{X}^{2}$ hitung $<\mathrm{X}^{2}(1-a)(\mathrm{k}-3)$, dimana untuk tes awal baik kelas eksperimen maupun kelas kontrol nilai $X^{2}$ hitung lebih kecil daripada nilai $X^{2}(1-a)(k-3)$. Begitupula untuk tes akhir, nilai $X^{2}$ hitung lebih kecil daripada nilai $X^{2}(1-a)(k-3)$, baik di kelas eksperimen maupun kelas kontrol. Artinya, data tes awal dan tes akhir baik di kelas eksperimen maupun kelas kontrol terdistribusi normal.

\section{Uji Homogenitas}

Pengujian data homogenitas menggunakan uji-F dengan kriteria jika $F_{\text {hitung }}<F_{\text {tabel }}$ maka data homogen. Hasil uji homogenitas dari kelas eksperimen dan kelas kontrol dapat dilihat pada Tabel 4.

Tabel 4 Hasil Uji Homogenitas Kelas Eksperimen dan Kelas Kontrol

\begin{tabular}{|c|c|c|c|c|c|}
\hline No & Kelas & $\bar{X}$ & $\mathrm{~F}_{\text {hitung }}$ & $\mathrm{F}_{\text {tabel }}$ & Keputusan \\
\hline 1 & $\mathrm{E}$ & 7,15 & \multirow{2}{*}{1,34} & 1,82 & $\begin{array}{c}\text { kedua } \\
\text { data } \\
\text { homogen }\end{array}$ \\
\hline 2 & $\mathrm{~K}$ & 6,09 & &
\end{tabular}

Berdasarkan Tabel 4, nilai $F_{\text {hitung }}<F_{\text {tabel. }}$ Hal ini menunjukkan bahwa data tersebut memiliki varians yang sama (homogen).
Uji Hipotesis

Pengujian hipotesis ini menggunakan statistik parametrik uji-t (uji dua pihak). Data hasil pengujian statistik tes awal dan tes akhir dapat dilihat pada Tabel 5.

Tabel 5 Uji Hipotesis Posttest Kelas Eksperimen dan Kelas Kontrol

\begin{tabular}{|c|l|c|c|c|c|}
\hline No & \multicolumn{1}{|c|}{ Kelas } & $\overline{\mathbf{X}}$ & $\mathbf{t}_{\text {hitung }}$ & $\begin{array}{c}\mathbf{t}_{\text {tabel }} \\
(\boldsymbol{\alpha = 0 , 0 5 )}\end{array}$ & Keputusan \\
\hline 1 & Eksperimen & 13,47 & 3,55 & 2,00 & $\begin{array}{c}\mathbf{H}_{\mathbf{0}} \\
\text { diterima }\end{array}$ \\
\hline 2 & Kontrol & 12,63 & & & Kima \\
\hline
\end{tabular}

Berdasarkan data pada Tabel 4 dengan kriteria pengujian dimana $\mathrm{H}_{0}$ diterima jika $\mathrm{t}<\mathrm{t}_{(1-\mathrm{a})}$ pada taraf signifikansi $\mathrm{a}=0,05 \mathrm{dan} \mathrm{dk}=62$, diperoleh $\mathrm{t}_{0,975(62)}=$ 2,00 . Berdasarkan hasil perhitungan diketahui 3,55 > 2,00 . Hal ini menunjukkan bahwa nilai thitung berada di luar daerah penerimaan $\mathrm{H}_{0}$. Artinya terdapat perbedaan hasil belajar siswa antara kelas eksperimen dengan kelas kontrol. Artinya sebelum diberi perlakuan, kemampuan awal siswa pada kelas eksperimen dan kelas kontrol berbeda.

Hasil Angket Inventori Pendekatan Metakognitif

Pada akhir kegiatan belajar mengajar, siswa harus menjawab kuesioner strategi pendekatan metakognitif. Skor pendekatan metakognitif berskala 45-180. Skor tertinggi yang diperoleh siswa adalah 145 sedangkan yang terendah adalah 77. Hasil dari skor inventori pendekatan metakognitif dapat dilihat pada Tabel 6.

Tabel 6 Hasil Skor Inventori Pendekatan Metakognitif

\begin{tabular}{|l|c|c|}
\hline No. & $\begin{array}{c}\text { Skor Pendekatan } \\
\text { Metakognitif }\end{array}$ & Frekuensi \\
\hline $\mathbf{1}$ & $135-180$ & 13 \\
\hline $\mathbf{2}$ & $90-135$ & 11 \\
\hline $\mathbf{3}$ & $45-90$ & 8 \\
\hline $\mathbf{4}$ & $0-45$ & - \\
\hline \multicolumn{2}{|c|}{ Jumlah } & 32 \\
\hline
\end{tabular}

\section{Pembahasan}

Berdasarkan dari kegiatan pembelajaran yang telah dilakukan dari awal hingga akhir pertemuan, diperoleh skor rata-rata untuk tes awal (pretest) 9,38. Kemudian setelah melalui proses pembelajaran selama tiga kali pertemuan, siswa diberikan lagi tes akhir (posttest), dimana soal pada tes awal dan tes akhir adalah sama. Maka diperoleh skor rata-rata untuk posttest sebesar 13,47. Dari kedua hasil pretest dan posttest ini, terlihat dengan jelas adanya perubahan tingkat rata-rata skor yang diperoleh oleh siswa, atau dapat disimpulkan mengalami 
ISSN 23383240

peningkatan skor rata-rata. Jadi, bisa dikatakan bahwa dari peningkatan skor rata-rata tersebut, peran dari penggunaan media powerpoint dengan metakognitif mempengaruhi hasil belajar fisika siswa.

Perbedaan skor rata-rata antara pretest dan posttest ini,dapat dipengaruhi oleh banyak faktor. Diantaranya, sebagian siswa yang awalnya memiliki cara atau strategi belajar yang mungkin masih asalasalan, setelah dijelaskan tentang bagaimana itu strategi belajar metakognitif dapat menjadi salah satu cara mencapai ketuntasan belajar, para siswa tersebut menjadi termotivasi untuk mengubah cara bejar mereka menjadi lebih baik lagi. Selama kegiatan belajar, siswa juga tidak dituntun harus mendapat nilai yang tertinggi, tetapi siswa dibimbing bagaimana menerapkan dan menggunakan waktu belajar mereka dengan cara belajar yang baik dan dengan sendirinya mereka akan mudah memahami materi yang diberikan hingga tanpa mereka sadari hasil belajar merekapun ikut berubah menjadi jauh lebih baik dari sebelumnya.

Berdasarkan hasil pengujian hipotesis yang telah dilakukan setelah diberikan perlakukan pada kelas yang menjadi sampel, terdapat pengaruh strategi belajar metakognitif terhadap hasil belajar fisika siswa. Hal ini dapat dibuktikan dengan ditolaknya pasangan hipotesis $\mathrm{H}_{\circ}$ yaitu diperoleh nilai dari $t_{\text {hitung }}$ $>$ tabel dan diterima pasangan hipotesis $H_{1}$. Sedangkan untuk hasil uji normalitas data yang meliputi tes awal (pretest) dan tes akhir (posttest), diperoleh harga $X$ 2hitung dan $X^{2}$ tabel pada tabel di atas, dapat dilihat harga $X^{2}$ hitung $<X^{2}$ tabel. Hal ini berarti data pretest dan posttest terdistribusi normal. Pembelajaran fisika yang menyenangkan dan lebih bermakna dapat diciptakan dengan adanya kreativitas guru dalam merancang pendekatan yang digunakan dalam pembelajaran, sehingga hasil belajar siswa dapat meningkat.

Menurut Atma (6), salah satu pendekatan pembelajaran yang dilandasi konstruktivisme dalam upaya meningkatkan proses kemampuan berpikir dan bagaimana berpikir terbaik untuk dapat memecahkan masalah fisika sehingga menjadikan siswa lebih aktif dan kreatif dalam belajar adalah pembelajaran melalui pendekatan metakognitif.

Hal ini juga berpedoman pada penelitian yang sebelumnya yang telah dilakukan oleh Muisman (7) pada tahun 2005, dimana hasil penelitiannya menunjukkan adanya hubungan yang signifikan antara strategi-strategi belajar metakognitif terhadap hasil belajar ekonomi siswa SLTPN 2 Banyuwangi.

\section{KESIMPULAN}

Berdasarkan hasil dan analisis data penelitian, maka dapat disimpulkan bahwa terdapat pengaruh penggunaan media powerpoint dengan pendekatan metakognitif terhadap hasil belajar fisika siswa. Hal ini dapat diketahui melalui hasil pengujian hipotesis dua pihak (uji-t) diperoleh thitung $=3,55$ dan $t_{\text {tabel }}=2,00$ dengan taraf nyata, dimana $\mathrm{H}_{\circ}$ ditolak dan $\mathrm{H}_{1}$ diterima. Hal ini menyatakan bahwa terdapat perbedaan hasil belajar fisika siswa yang diberi perlakuan menggunakan media powerpoint dengan pendekatan metakognitif berbasis masalah dengan kelas siswa yang diberi perlakuan secara konvensional. Dengan media yang digunakan dalam proses pembelajaran, siswa menjadi lebih aktif dalam pembelajaran dan terampil dalam mengerjakan soalsoal yang dibangun oleh kesadaran dan kemampuan berpikirnya sendiri, maka pembelajaran dengan pendekatan metakognitif akan menyadarkan siswa tentang kognitif yang dimilikinya.

\section{DAFTAR PUSTAKA}

[1] Agustina, L. (2011). Penerapan Strategi Belajar Metakognitif Dalam Meningkatkan Kualitas Belajar Siswa Pada Materi Cahaya Di Kelas VII SMP Negeri I Mojokerto: Jurnal Pendidikan Fisika Indonesia Jurusan Fisika FKIP Universitas Negeri Surabaya.

[2] Arsyad, A. (2007). Media Pembelajaran. Jakarta: PT RajaGrafindo Persada.

[3] Maulana. (2008). Pendekatan Metakognitif Sebagai Alternatif Pembelajaran Matematika untuk Meningkatkan Kemampuan Berpikir Kritis Mahasiswa PGSD. Skripsi (tidak diterbitkan). Universitas Pendidikan Ganesha.

[4] Lucky dan Madewi, (2011). Penerapan Strategi Belajar Metakognitif Dalam Meningkatkan Kualitas Belajar Siswa Pada Materi Cahaya Di Kelas VII SMP Negeri I Mojokerto: Jurnal Pendidikan Fisika Indonesia Jurusan Fisika FKIP Universitas Negeri Surabaya.

[5] Sudjana. N dan Ibrahim. (2009). Penelitian dan Penilaian Pendidikan. Bandung: Sinar Baru Algesindo.

[6] Atma, M. (2010). Pembelajaran Matematika Dengan Pendekatan Metakognitif BerbasisMasalah Kontekstual. Fakultas keguruan dan Ilmu Pendidikan. Program Studi Pendidikan Fisika. Universitas Riau.

[7] Muisman, (2005). Analisis Jalur Hasil Belajar Mata Pelajaran Ekonomi Berdasarkan Kecerdasan, Strategi-Strategi Metakognitif, dan Pengetahuan Awal. [Online]. Tersedia 
Jurnal Pendidikan Fisika Tadulako (JPFT) Vol. 3 No. 1 ISSN 23383240

:http://www.damandiri.or.id/detail.php?id=288/

[12 Oktober 2014] 